\title{
Survival Dilemma of Small and Medium Commercial Banks in China
}

\author{
Ziyao Lei \\ School of Economics and Management, Wuhan University, Wuhan, Hubei, 430072, China
}

Keywords: small and medium commercial banks, development challenges

Abstract: Small and medium commercial banks in our country have experienced a rapid development in the 1990s. However, due to the problems accumulated during the rapid development and the various shocks brought about by the current financial environment, small and medium commercial banks are facing survival difficulties. In this paper, we analyze the obstacles faced by small and medium commercial banks in China from the perspective of history and the current financial environment, and propose countermeasures.

\section{Problems of Small and Medium Commercial Banks in History}

\subsection{History of the development of small and medium-sized commercial banks}

China's small and medium-sized commercial banks are mainly for the five major State-owned commercial banks, generally speaking, mainly including joint-stock commercial banks, urban commercial banks, urban credit unions, rural credit unions and other financial institutions.

The small and medium commercial banks in our country mentioned in this paper are relative to the five largest state-owned commercial banks. In general, it mainly includes financial institutions such as joint-stock commercial banks, urban commercial banks, urban credit unions and rural credit unions.

Before 1979, China's banking industry was monopolized by the People's Bank of China, and in 1983, the State Council decided that the People's Bank of China would exclusively exercise the functions of a central bank and set up a number of state-owned specialized banks, and in 1987, China's first joint-stock bank, the Bank of Communications, was established, marking the breaking of the pattern of domination by four wholly state-owned commercial banks. As the process of reform and opening up in China continues to advance, the demand for loans from small and medium-sized enterprises is increasing. The country has also continued to introduce policies to deepen financial reform, creating good conditions for the development of small and medium-sized banks. New types of banks are emerging, and small and medium-sized banks are growing rapidly.

At the beginning of the reform and opening up, in order to vigorously develop the rural credit market, the State restored the Agricultural Bank of China to lead rural credit cooperatives, which developed rural finance and opened the prelude to the reform of China's banking industry.In 1978-1998, the rural small and medium-sized financial institutions in the majority of counties and townships were called agricultural credit cooperatives, and there were tens of thousands of independent legal entities of agricultural credit cooperatives nationwide, with total assets amounting 
to 738 billion yuan, and at the same time to meet urban financial needs. In line with the reform of rural finance, the Central Government has set up mass cooperative financial organizations in cities, the Urban Credit Cooperative (hereinafter referred to as "urban credit cooperatives"), to provide financial services to urban collective enterprises, individual businessmen and urban residents. By the end of 1999, there were 90 city commercial banks and 836 prefecture-level city credit unions in China, with total assets in local and foreign currency amounting to 674.5 billion yuan.

But by the late 1990s, the problems accumulated by small and medium-sized banks in the course of their rapid development in the early years were constantly exposed. The presence of mismanagement, irregularities, local interventions, etc., as well as the competitive pressure brought about by the gradual deepening of the reform of state-owned commercial banks, have led to a significant decline in the major market share of small and medium-sized banks. Moreover, non-performing assets are increasing and the financial situation is deteriorating, and insolvency is common. The overall creditworthiness of small and medium-sized banks is threatened and liquidity risks are prominent. Faced with this scenario, the state began to clean up and restructure small and medium-sized banks and continuously reformed them.

\subsection{Problems accumulated by small and medium-sized commercial banks in the early years of rapid development}

In general, small and medium-sized banks have left behind three inherent problems in their development process.

(1) Size constraints hinder the future development of small and medium-sized banks: due to their small size relative to state-owned commercial banks, the public trust in them is lower than that in state-owned commercial banks. As a result, they represent a small proportion of total assets and often face insolvency problems. Moreover, due to the small size and strength of individual small and medium-sized banks, their liquidity risk is more pronounced and they are highly vulnerable to run-offs.

(2) The quality of capital hinders the sustainable development of small and medium-sized banks: at the early stage of development, many agricultural and urban credit cooperatives blindly "deposit-establishment", absorbing deposits at no cost and neglecting the profitable management of banks in the long run. This resulted in the bank facing severe operating losses at a later stage. And, because their management of safety and liquidity was not mature enough at the time, and they tried to prevent and mitigate risk through economies of scale, they had a high proportion of low-quality, sunk assets under the old management system, resulting in a heavy historical burden in their later years.

(3) Irregular operation and management hinder the healthy development of small and medium-sized banks: from the perspective of external intervention, since most of the small and medium-sized banks in China are restructured or merged by urban and agricultural credit cooperatives, their shareholding structure is unreasonable, and a dominant share is a common problem. Shareholders of large enterprises stationed in banks and local governments intervene in and even control the day-to-day operations of small and medium-sized banks, making the corporate governance of small and medium-sized banks less independent. In 2019, for example, a takeover of the 20-year-old Bau Shang Bank was implemented because the Tomorrow Group, which holds 89\% of its shares as the largest shareholder, illegally and illegally took up a large amount of funds and had difficulty returning them overdue for a long period of time, resulting in serious credit risks for Bau Shang Bank. As an internal mechanism, the level of regulation of small and medium-sized banks is also generally inadequate. Inadequate wind control system, unreasonable internal monitoring and management mechanism, uneven quality of staff, etc., make risk cases occur from 
time to time.

\section{Difficulties faced by small and medium-sized commercial banks in the current financial environment}

After more than 40 years of financial reform in China, small and medium-sized commercial banks, represented by the City Commercial Bank, the Agricultural Commercial Bank and the Agricultural Credit Union, have made breakthroughs in the management system, property rights reform and corporate governance, and they are constantly developing new businesses and striving to avoid homogenization of banking services. However, in recent years, with the continuous changes in the internal and external economic environment and the strengthening of financial regulation, small and medium commercial banks still face many obstacles to development.

\subsection{Rising costs of funding sources under marketized interest rates}

The interest rate, as the price of funds, is an important part of the reform of the price system. China's interest rate marketization reform began in 1996 when the People's Bank of China liberalized interbank lending rates. Since then, market-based interest rate reforms have been gradually introduced in the bond and credit markets.

Since its commercialization, China's banking industry has been adhering to the concept of "deposit-based banking". Although in the early period, some banks blindly pursued "deposit banking", causing banks to accumulate many non-performing assets, but overall, this concept is still a great contribution to the development and growth of the banking industry in China. And despite the continuous development and reform of China's banking industry, deposits are the source of survival of commercial banks, and the absorption of deposits is still the most important part of bank operations, the number of core deposits will reflect the core competitiveness of banks.

In the early days, when our country was still in the interest rate control phase, commercial banks tended to homogenize their business among themselves, simply focusing on general deposits. As the interest rate marketization reform process advances, commercial banks will have greater rights to regulate their interest rates based on their operational needs and capital adequacy. As a result, banks, in order to obtain sufficient capital and profits, will raise deposit rates in order to attract customers, increasing the cost of absorbing deposits and undermining the traditional ability to earn profits by relying on deposit and loan spread income. In addition, as a result of the deregulation of interest rates, which are mainly determined by market supply and demand, commercial banks are directly exposed to increased interest rate risk. This tests the interest rate risk assessment system and early warning mechanism of small and medium-sized banks. In addition, against the background of the marketization of interest rates and increasingly fierce competition in the banking industry, small and medium-sized banks will have to sink the evaluation conditions of their customer targets, by tapping the less creditworthy customers to obtain higher profits and seize market share. This poses a challenge to the pricing power of small and medium-sized banks, as well as their wind control capabilities.

\subsection{Declining asset quality in a downward economic cycle}

With the deepening of China's economic reform, as well as the "three go one drop one make up" supply-side reform, some of China's high capacity, high leverage, technology and management level is not high enough for enterprises, has been seriously hampered, the level of profitability is reduced, the market for some overcapacity industries of commodity prices also fell. This has led to a "double rise" in the volume of non-performing loans and non-performing loan rates of commercial banks. 
Especially for small and medium-sized commercial banks, whose main lending target is small and medium-sized private enterprises, customer strength is relatively weak, more prone to non-performing loans. As can be seen from Figure 1, after the "supply-side reform" was proposed in November 2015, the non-performing loan rates of the City Commercial Bank and the Agricultural and Commercial Bank continued to rise, and were significantly higher than those of large commercial banks and joint-stock commercial banks. Their non-performing loans climbed from 85.5 billion yuan and 109.1 billion yuan in 2014 to 40.4 billion yuan and 615.5 billion yuan in 2019, accounting for $16.88 \%$ and $25.50 \%$ of the proportion of non-performing assets of commercial banks in China, respectively, from 10.15\% and 12.95\% in 2014.

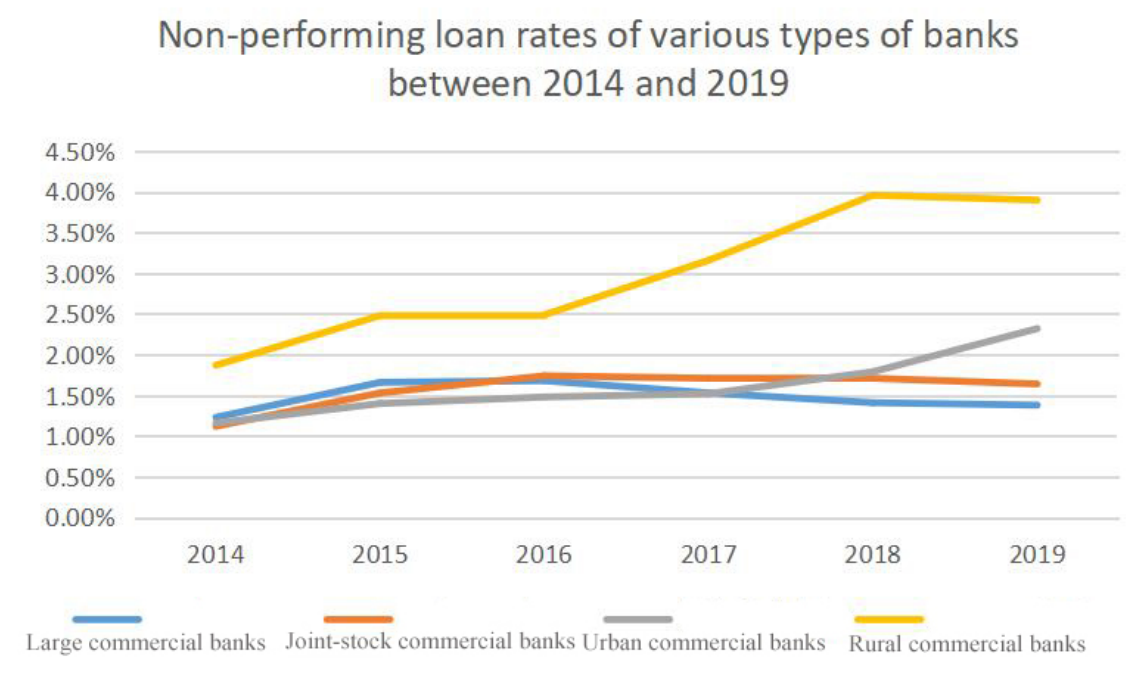

Figure. 1 Data obtained from the official website of the China Banking and Insurance Regulatory Commission

From the internal perspective of banks, due to the impact of economic downward pressure, some small and medium-sized banks use leverage, maturity mismatch and other methods to make investments, resulting in increased market risk and liquidity risk of banks, asset quality continues to decline. At the same time, according to the guiding idea of "de-capacity", banks must improve the traditional profit model, establish the concept of "merchant bank + investment bank + transaction bank", and customize personalized services for enterprises in different industries and different stages of their life cycle. This is a big challenge for small and medium-sized banks, which are at a disadvantage in terms of technology, management level, reserve resources and personnel quality compared to large commercial banks. The asset margins of City Commercial Bank and Agribusiness Bank also fell to $0.70 \%$ and $0.82 \%$ respectively by the end of 2019 , from $1.12 \%$ and $1.38 \%$ in 2014 .

\subsection{The rapid development of Internet finance has had an impact on traditional business models}

In the era of rapid development of market economy and financial technology, a variety of Internet financial platform business has brought a serious impact on the core business of traditional commercial banks, such as deposit and loan, payment, settlement and other core business, causing the banking industry, which had become increasingly competitive, has greater pressure to survive. Small and medium-sized commercial banks in China tend to adopt a hierarchical system of branching or functional departmentalized internal management structure, as well as offline business 
forms. The management concept of "light organization" of Internet finance has made it faster and more efficient to handle business, challenging the more artificial business model of traditional small and medium-sized banks; the advantages of its digital, intelligent and informatization platform have overturned the physical network model of traditional small and medium-sized commercial banks, and gradually occupied the market share of small and medium-sized banks deep into townships. In addition, its high yield characteristics have quickly scavenged the market for a lot of money. For example, the banking business that most closely resembles the Tien Hsiang Balances business is the demand deposit business. The annualized yield of Tianhong Balance Bao 2017 is 6.8\%, which is much higher than the 0.35\% required by the People's Bank of China for demand deposits. Even though the annualized yield on Balance Treasure has fallen to $2.65 \%$ by the end of 2019 , it is still well above the PBoC's deposit rate.

\section{Solutions for small and medium-sized banks}

Faced with their own resource constraints and the obstacles of the external environment, small and medium-sized banks should continuously improve their internal management structure and explore the path of innovation.

First, small and medium-sized commercial banks should strengthen the prevention and control of non-performing loans. The most traditional method used by banks for credit analysis of enterprises is the 6C principle, in addition to the 18P, 5W, CAMPARI and other lending frameworks that serve as guidelines for banks to conduct credit analysis. Under this, banks use traditional financial technical analysis, non-financial analysis, etc. to make specific ratings of companies. In fact, however, small and medium-sized banks are mainly lending to SMEs. Their financial reporting is incomplete and many small businesses do not even have a credit history. Small and medium-sized banks should improve the system for assessing loans, determine the true willingness of enterprises to lend and their ability to repay, and make better forecasts of the risks they pose.

Secondly, small and medium-sized commercial banks should establish a reasonable shareholding structure to prevent the existence of "internal controllers", ensure that shareholders act in accordance with their authority and avoid excessive interference by them in the daily business activities of the bank. At the same time, an adequate system of related-party transactions should be established to prevent illegal transactions from occurring. In addition, banks can create incentives for better development through internal shareholding by employees.

Finally, small and medium commercial banks should expand their business, increase innovation in network technology, and strive to transform to digital scenario. We need to improve the integration of big data, increase the development of mobile banking, make the management structure light, facilitate the business process, and make the service mode intelligent, so as to better keep up with the current financial technology development trend.

\section{References}

[1] Wen B., Huo T.. Small and medium-sized banks' dilemmas and the road to breakout [J]. Tsinghua Financial Review, 2019 (11): 46-48

[2] China Minsheng Bank Research Institute Project Group. Deposit business difficulties and future development strategies of small and medium-sized banks [J]. Commercial Banking.

[3] Kan, Fang-Ping, Xia, Hong-Tao. The plight of small and medium-sized banks in China and the way out [J]. Hubei Rural Finance Research, 2001 (1): 17-20.

[4] Zhang, C.Q.: The current dilemma of small and medium-sized banks in China and the way out [J]. Banker, 2019 (7). 